\title{
TRACING THE HISTORY OF MAKARA AK-MAK-247 IN THE RIJKSMUSEUM AMSTERDAM
}

\section{Introduction}

The makara is a fabulous, composite animal that is mentioned in Sanskrit literature and depicted on Indian temples. In the process of intercultural exchange between India and Southeast Asia, this composite animal was also adopted in the Hindu and Buddhist architecture of Java. There it most commonly features as a monstrous head with an open jaw and an elephant's trunk. Two beautiful Javanese makara are currently exhibited in the Rijksmuseum's Asia Pavilion. The provenance of one of these (AK-MAK-248) has been known since it first came into the collection of the VVAK in 1931.' It came from the Bubrah temple, now part of the Prambanan archaeological park (near Yogyakarta). It was originally located at the lower left side of the main entrance of this temple, which has long been in ruins. Its counterpart, originally at the lower right side of the entrance, is still at the site. In contrast, little was known about the other makara (fig. 1). New art historical research has, however, changed this situation. In this article we present the results. William Southworth traces its collection history and Marijke Klokke its original provenance.

\section{Isidore van Kinsbergen and 'makara' AK-MAK-247}

Among the famous series of photographs taken in Java by the pioneer photographer Isidore van Kinsbergen between 1863 and 1867, and later published as a set of 322 prints under the title Oudheden van Java, is a number of plates depicting sculptures in the former Lichte collection at Jogjakarta. ${ }^{2}$ This sculpture collection had been amassed by a private

U landowner during the mid-19th century from Central Javanese temple sites located northeast of Yogyakarta and were proudly displayed in the garden of his estate at Tandjoeng Tirta near Prambanan. The collection is first mentioned by visitors to Central Java in 1845 , but by the time of Hoepermans' visit in 1864-7, Lichte himself had died and the estate with its collection of Javanese antiquities had come under new ownership. ${ }^{3}$ Van Kinsbergen visited the estate and took nine photographs of the sculptures there between July and September 1865 (nos. 191-199). One of these photographs (no. 192) shows a group of four sculptures featuring a warrior in front of the fragmented legs of a lion, raised between two makaras; that on the left with a man in its jaws and that on the right with a lion (fig. 2). In 2008, Pauline Lunsingh Scheurleer noticed the similarity between the makara standing on the right of this photograph and the previously unknown makara sculpture in the collection of the VVAK (AK-MAK-247). With the help of the museum photographers, she was able to definitively confirm this identification (fig. 3). ${ }^{4}$ 

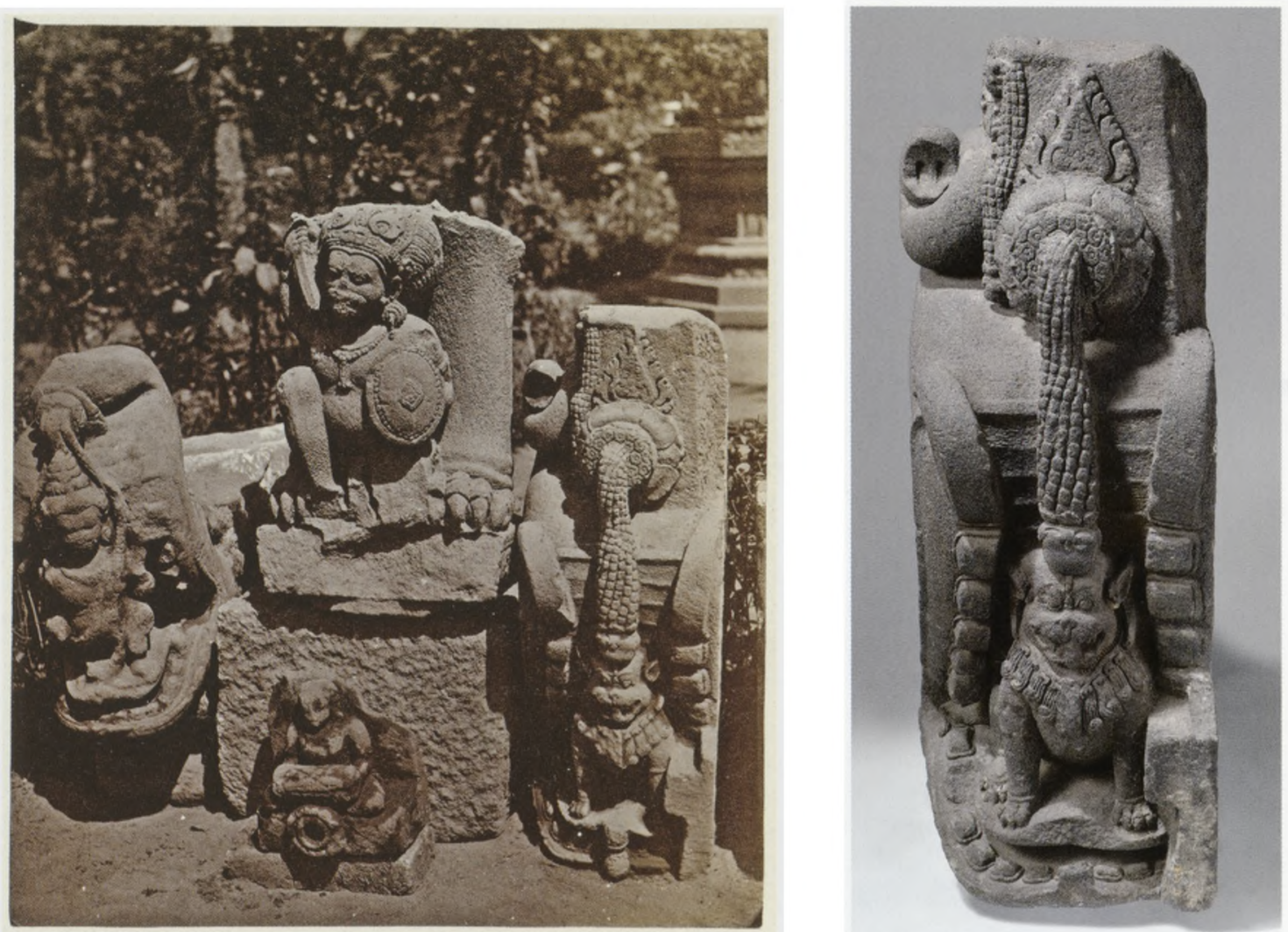

Cat: $2: 192$

Fig. 2 (above left)

\section{Oudheden van Java}

no. 192, Rijksmuseum, RP-F-2005-159-52. Photograph:

Van Kinsbergen.

Fig. 3

Makara AK-MAK-247, front view.

Photograph: Rijksmuseum Amsterdam.

\section{The later history of the sculpture}

On the basis of this identification, it has been possible to reconstruct the later history of the sculpture. As far as we know, the makara remained on display at the former Lichte estate until the end of the 19th century. In January 1902, plans were formulated by the newly-created colonial Commission for Archaeological Research in Java and Madura for a permanent museum at Yogyakarta that would bring together the different archaeological collections in both public and private ownership. This new museum was to be formed around the collection of an Archaeological Society (Archaeologische Vereeniging) that had been founded by Dr. I. Groneman in 1885 , supplemented by pieces displayed in front of the Residency building at Yogyakarta and on other private estates. Through negotiations with G.A.S. Hempenius, the then administrator of the former Lichte estate, thirty-two sculptures were brought from Tandjoeng Tirta and incorporated into the Archaeological collection at Yogyakarta. ${ }^{5}$ Here they were described in detail by Jan Knebel in May 1902, including the makara, which was listed as number 253 in the inventory. ${ }^{6}$

Sadly however, the prospective Museum at Yogyakarta was finally cancelled by the colonial government in December 1912, and Dr. N.J. Krom, then chairman of the Commission, actively sought a new home for the collection. A total of 11 sculptures were chosen for the Museum in Batavia (now the National Museum, Jakarta), while a small group were kept in the garden of the residency building at Yogyakarta. The vast majority of sculptures however ${ }^{2}$. 
were taken to Magelang on the understanding that a new Museum building would be constructed for them there. From the list of numbers included in the accompanying report, we know that the makara was among them. ${ }^{7}$

Unfortunately, these plans too came to nothing and apart from another seven sculptures taken in by the Batavia Museum, ${ }^{8}$ the whole collection was returned to the Prambanan plain by early $1918 .^{9}$ Some of the sculptures were placed along the southern enclosure wall of the temple of Loro Jonggrang, where they were protected from the elements by a tin roof constructed for this purpose. Most of the architectural elements however, including makara no. 253, were arrayed near the secondary shrines of Candi Loro Jonggrang, where their location was recorded by Martha Muusses in $1923 .{ }^{10}$

It is clear from these reports that since its foundation in 1901, the Archaeological Commission and later Archaeological Service had become increasingly anxious to find a secure home for these sculptures. After a number of failed attempts, this concern can only have been heightened by the drastic reduction of funding and enforced cutbacks to the Service after 1930. It is into this context that the VVAK's initial request first arrived for a consignment of sculptures from Java and explains why Bosch was so willing to lead H.K. Westendorp to Prambanan in order to make his selection. ${ }^{11}$

\section{The original location}

In tracing the collection history of this makara however, we did not come across any information about its whereabouts before it was brought to the estate at Tandjoeng Tirta; neither Van Kinsbergen's photograph nor the older documentation was able to disclose its original provenance. Nevertheless, with the help of our visual knowledge of Central Javanese temple ornaments, it appeared not too difficult to establish this. The makara immediately reminded us of the early Central Javanese style as found on the temples of the Sewu temple complex and surrounding temples, such as Lumbung, Bubrah, and Gana. Characteristic for this style are slit eyes, a necklace with a row of pearls, and a lion with all legs placed firmly on the makara's tongue. More important perhaps, is the general artistic 'feel' of this makara that places it securely in this style group. Checking our photographs of the makaras of this group, we found that the Rijksmuseum makara is almost identical to the makaras that figure on the four entrances of the main temple of the Sewu complex (figs. 4 and 5 ).

Most early Central Javanese makaras show a thick cord of pearl strings that hangs down from a flower rosette - depicted on the trunk - down to the lion's head. The lion, too, often holds a cord of pearl strings in his open jaws which hangs down between his front legs. Unique for the makaras at the four entrances of Sewu's main temple is a third cord of pearl strings at the top of the makara, which falls down to one side of the flower rosette with a characteristic bend. This third cord of pearl strings, damaged in the example in figure 4, but intact in that in figure 5, can also be observed in AK-MAK247. The makaras in figures 4 and 5 still show the lower cord of pearl strings in the lion's jaws, which has, however, almost completely disappeared in AKMAK-247 (fig. 3). Also unique for these Sewu makaras is the way in which they were cut from one piece of stone. In the original design the scroll motif above the eye was circular, but because one quarter of it was cut on an adjacent stone, this part is now missing in AK-MAK-247 (fig. 1), as in most other cases (compare figs. 4 and 5). 
Fig. 4

Makara on the northern entrance of the main temple of the Sewu temple complex. Photograph: Marijke Klokke.

Fig. 5

Makara on the southern entrance of the main temple of the Sewu temple complex. Photograph: Marijke Klokke.
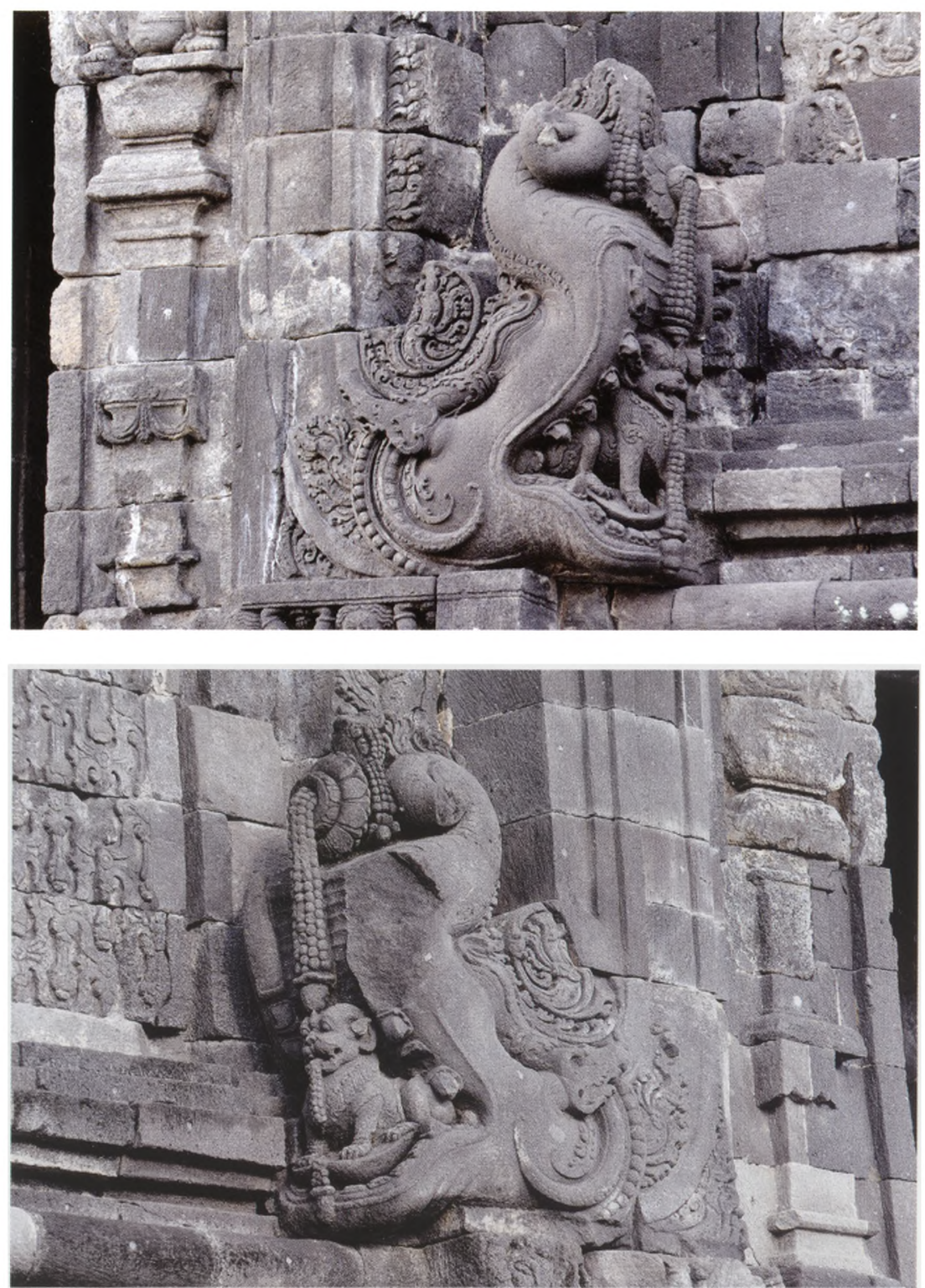

When comparing the various Sewu makaras we also note some differences. For instance, AK-MAK-247 (figs. 1 and 3) shows a rosette in the form of a lotus (padma), while the makara in figure 4 shows a rosette in the form of a blue lily (utpala). Also, the ends of the lion's mane in AK-MAK-247 form thick curls, while those of the lion in figure 4 hang down in separate thin strands. Such differences are characteristic of Central Javanese art in general, which hardly ever shows us two exactly identical sculptures. We need to keep in mind that all sculptures were made by hand and are therefore unique pieces. Apparently there was a certain amount of freedom in the execution of the details, and some of these may also have been carved by different hands. If makara AK-MAK-247 does indeed come from the main temple of the Sewu temple complex, as its similarity to the makaras of that temple suggests, this would mean that at least one makara is missing there. Walking around the 
Fig. 6

Main (eastern) entrance of the main temple of the Sewu temple complex. Photograph: Marijke Klokke.

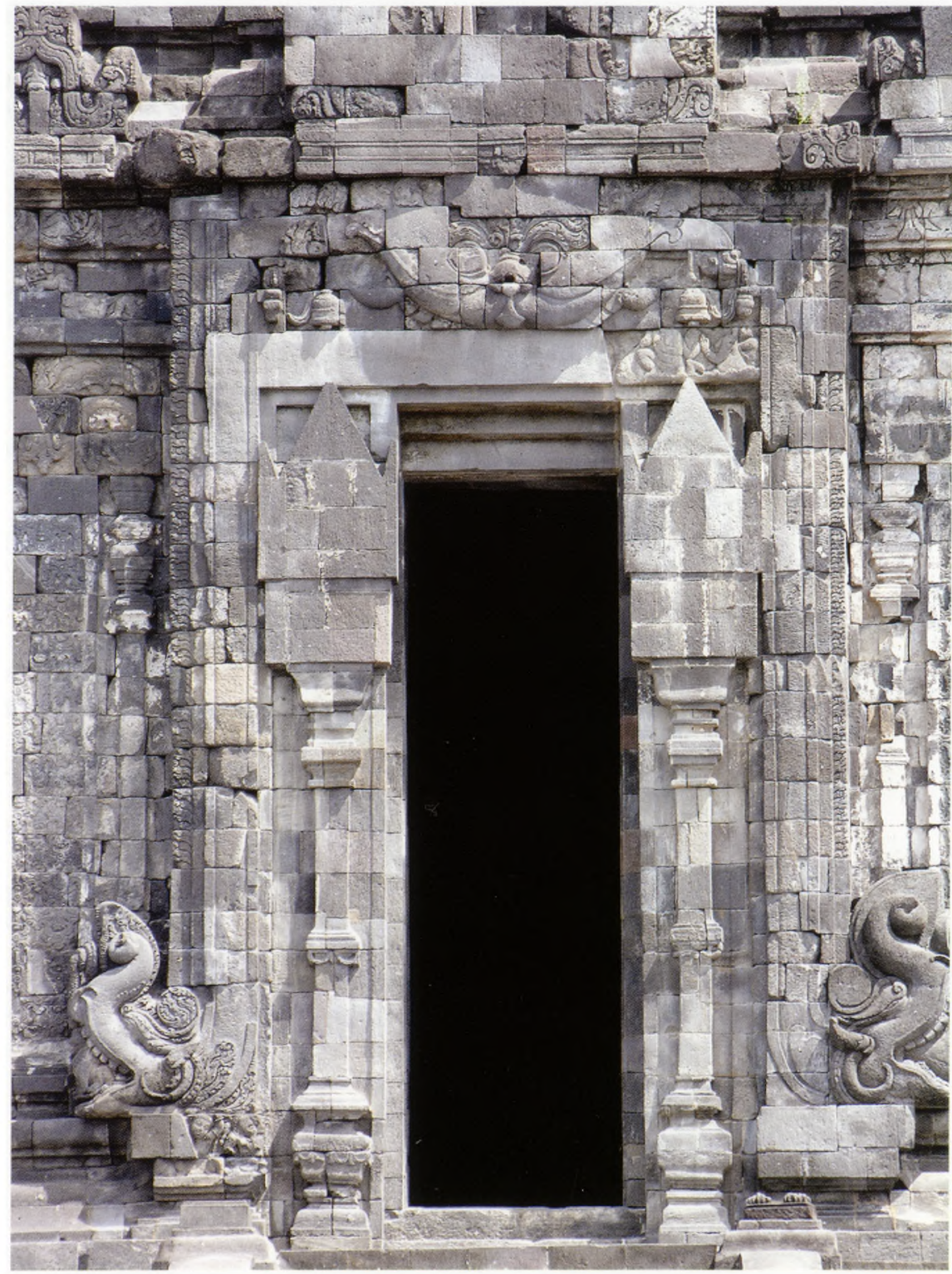

temple, we noticed that indeed one - and only one - makara is missing, that on the right side(!) of the eastern, main entrance of the temple (fig. 6). To compensate for its absence, a new stone sculpted in the form of the missing makara has been placed there, probably during the last restoration of the temple in the 1980s. It should be noted that the surrounding wall surface on the right side of the entrance has also been restored with new blocks of stone, so that the outline of the replacement makara is not the same as the original. However, we now know where the original makara is: it is AK-MAK-247 in the Rijksmuseum Amsterdam. 
- William Southworth is curator of Southeast Asian Art at the Rijksmuseum in Amsterdam.

- Marijke Klokke is Professor of Art and Material Culture of South and Southeast Asia at Leiden University and curator South and Southeast Asia at the National Museum of Ethnology (National Museum of World Cultures) in Leiden.

\section{Literature}

F.D.K. Bosch (ed.), 'Inventaris der Hindoe-oudheden op den grondslag van Dr. R. D. M. Verbeek's Oudheden van Java. II. Midden-Java', in: Rapporten van den Oudheidkundigen Dienst in Nederlandsch-Indië 1915: pp. 1-376.

F.D.K. Bosch, 'Oudheidkundig Verslag over het Tweede Kwartaal 1917', in: Oudheidkundig Verslag 1917: pp. 37-51.

F.D.K. Bosch, 'Oudheidkundig Verslag over het Eerste Kwartaal 1918', in: Oudheidkundig Verslag 1918: pp. 1-15.

N.W. Hoepermans, 'Hindoe-oudheden van Java', in: Rapporten van den Oudheidkundigen Dienst in Nederlandsch-Indië 1913: pp. 73-361. [Written between 1864 and 1867.]

E.F. Jochim, 'Beelden te Djokjakarta', in: Rapporten van de Commissie in NederlandschIndië voor oudheidkundig onderzoek op Java en Madoera 1912: pp. 90-102.

J. Knebel, 'Beschrijving van de archaeologische verzameling te Djogdjakarta', in: Rapporten van de Commissie in Nederlandsch-Indië voor oudheidkundig onderzoek op Java en Madoera 1902, Bijlage (15): pp. 35-145.

N.J. Krom, 'Oudheidkundig Verslag over het Vierde kwartaal 1912', in: Oudheidkundig Verslag 1912: pp. 73-9.

Martha A. Muusses, 'De beelden te Prambanan', in: Oudheidkundig Verslag 1923, Bijlage J: pp. 110-37.

William A. Southworth, 'F.D.K. Bosch and twelve Central Javanese sculptures from the Archaeological Service of the Dutch East Indies', in: Aziatische Kunst 43/3-4 (2013): pp. 62-71.

Gerda Theuns-de Boer en Saskia Asser, Isidore van Kinsbergen (1821-1905):

Fotopionier en theatermaker in Nederlands-Indië / Photo Pioneer and Theatre Maker in the Dutch East Indies, KITLV Press, Leiden; Huis Marseille, Amsterdam \& Uitgeverij Aprilis, Zaltbommel, 2005.

\section{Notes}

1. See Southworth 2013: 65, fig. 4.

2. Theuns-de Boer \& Asser 2005: 250-1.

3. Hoepermans 1913: 235-7.

4. Our sincere thanks are due to Pauline herself and to Cécile van der Harten and Frans Pegt from the photographic department of the Rijksmuseum.

5. Bosch 1918: 44-5.

6. Knebel 1902: 128-9.

7. Krom 1912: 78.

8. Bosch 1917: 50 .

9. Bosch 1918: 12 .

10. Muusses 1923: $111 \& 128$.

11. Southworth 2013: 63. 